\title{
CAML Milestones
}

With this December 2020 reboot, we are launching a new column that celebrates milestones of CAML and its members. We aim to share organization news, celebrate our colleagues' accomplishments, and document changes for future researchers looking back. Have news to share? Contact the co-lead editors to have your news published in the next issue!

\section{New roles}

Houman Behzadi began his new role as Head of the Marvin Duchow Music Library at McGill University May 1, 2019.

Dan Sich is the new Teaching \& Learning Librarian at Western University, a role which is responsible for Music as well as other Arts and Humanities. He started this role May 1, 2020.

\section{Retirements}

Lisa Philpott retired from the Music Library at Western University April 1, 2020, after nearly 38 years. She began part-time as a student worker in 1982 and moved to a full-time position in 1984.

\section{Awards}

Congratulations to Alastair Boyd (University of Toronto, retired) who won the Toronto Mendelssohn Choir's 2020 Choral Composition Competition. "Boyd's winning work, A Hymn on the Nativity, is an SATB setting of words by English poet and playwright Ben Jonson. TMC associate conductor Simon Rivard, who led the three-member competition jury, shares what impressed them: "Mr Boyd's submission exhibits many features that seduced the jury: interesting choice of lyrics; richness of the harmony; and a good balance between variety and unity between verses. We are looking forward to performing this piece in the coming month."' Read the full story here.

Congratulations to Cathy Martin (Marvin Duchow Music Library) who received the 2020 McGill Librarian Excellence Award. "Cathy was nominated by her colleagues for her excellence as a librarian, mentor and colleague. The Marvin Duchow Music Library staff rely on her clear vision and service implementation and they know that they can always approach her with new ideas. Cathy has created and manages an access services team to address any enhancements needed. Two recent examples are a service desk triage procedure and an $\mathrm{AV}$ equipment online reservation request system for Music faculty and students." Read the full citation here.

\section{New Members}

CAML has 9 new members this year - 4 joined CAML and 4 joined CAML/IAML. This brings the count to 77 members. 


\section{Book Launch}

Congratulations to Nina Penner (Brock University) who launched her new book Storytelling in Opera and Musical Theatre (Indiana University Press, Oct 2020).

\section{CAML NeWS}

CAML held its first election in seven years in summer 2020, with two candidates in the running for Member-At-Large. CAML became an incorporated association in the Federation for the Humanities and Social Sciences in 2013, which requires us to follow federal and Ontario rules around governance. This became relevant as we looked into holding an online AGM and an online election. We had no precedent to follow as this was CAML's first online election.

The Federation explains that as per the Canada Not-for-Profit Corporations Act, the organization needed to be able to verify the vote after the election while maintaining the anonymity of the individual voter.1 In 2016, Jan Guise, in her capacity as Nominations Officer, investigated various options and concluded that SurveyMonkey, which was also used by MLA (Music Library Association) for elections at that time, met CAML's election needs. However, SurveyMonkey does not allow for sufficiently anonymous voting and verification as required by these federal rules. The Federation recommended a number of other platforms. Carolyn Doi (Past President) and Kyla Jemison (Nominations Officer) evaluated these recommendations, determining that most of them were wildly beyond the needs and budget of CAML. We selected Election Runner because it offered the anonymous voting we needed and was reasonably priced at \$19USD per election.

Kyla worked with Houman Behzadi (President) to draft messages that Election Runner would send to our membership in English and French and Kyla set up the two candidates as the voting options. The platform has a section where we can enter more information about the voting options, so Kyla copied the biographical statements from our candidates there. It turns out that this information does not display well - voters must click on a button next to the candidate's name to view the biographical information. After several emails from confused voters, Kyla made a note in the documentation for future elections to include this information in the election announcement email.

Following the guidelines set out in the CAML constitution, we held the election one week after the CAML AGM and polling remained open for 2 weeks.

At the time of the election CAML had 58 members. Voter turnout was good; 41 people voted, $71 \%$ of the membership. It was a tight election, 23-18. Election Runner also offered a Fraud Analysis tool, which cheerfully announced that it was "unable to detect any potential voter fraud in this election." On the Monday following the close of the election, Kyla communicated the results to the members by email.

\footnotetext{
${ }^{1}$ Ideasldees, "Hosting a virtual annual meeting - Tenir une reunion annuelle virtuelle," YouTube video, 53:52 (April 20, 2020), https://www.youtube.com/watch?v=xnHdrLKLrCg\&feature=emb err woyt
} 